\title{
The Role of Trade Policy in the Performance of Nigerian Agricultural Sector: A Time Series Analysis
}

\author{
Ogunjinmi, O. O.* Oduyoye-Ejumedia, A. O. \\ Department of Economics, Lead City University, Ibadan, Nigeria
}

\begin{abstract}
There has been an increasing interest in understanding the role of trade policy in agricultural performance over the years. This time-series study investigates the impact of trade openness and domestic currency rate on agricultural performance in Nigeria within the period, 1981-2019. Using the autoregressive distributed lag (ARDL) approach, the study confirmed that there exists a long-run relationship between trade policy and agricultural performance in Nigeria. The result showed that trade openness has a significant and positive effect on agricultural performance in Nigeria. Further, the study confirmed that trade openness contributes more to agricultural performance in the long-run than in the short-run. However, exchange rate impacted negatively and significantly on agricultural performance in the long-run. Meanwhile, the short-run estimates showed that exchange rate has a significant and positive effect on agricultural performance. More so, it was gathered that interest rate affects agricultural performance negatively in Nigeria. There is need for government to embark on outward looking trade policy that supports the agricultural industry in terms of its exportation of indigenous commodities and stimulation of output growth.
\end{abstract}

Keywords: Agricultural output, trade openness, exchange rate, interest rates, ARDL.

JEL Classification: Q19, F13, E52.

DOI: $10.7176 / \mathrm{JESD} / 12-16-08$

Publication date:August $31^{\text {st }} 2021$

\section{Introduction}

Nigeria is endowed with a large expanse of arable land, mineral and natural resources which makes agriculture the main stay of the country's economy before and immediately after independence until the discovery of crude oil in commercial quantities in 1959. Nigeria has witnessed several twists and turns in the contribution of the agricultural sector to the growth of the economy. Hence, the fate of the agricultural sector remains a paradox. Agriculture plays a crucial role in transforming the socio-economic frontier of Nigeria. It has been a source of food and raw materials for the industrial sector, generation of employment, alleviation of poverty and improvement of income distribution (Anyanwu, 1997; Nwanji, Lawal, Asamu and Inegbedion, 2019).

Furthermore, agricultural output in Nigeria is determined by the dynamics of macroeconomic environment shaped by monetary and fiscal policy and most importantly trade policy. The contributions of agricultural sector to GDP have oscillated widely over the years. In 1970s, the annual growth rate of agricultural output was incredibly low standing at $1.7 \%$. The lowest ebb ever was $4.7 \%$ recorded in 1986 which coincided with the inception of the Structural Adjustment Programme (SAP) initiated by the Babangida's regime aimed at restructuring and diversifying the economy (National Bureau of Statistics, 2017). The institution also noted that the industry recorded a highest growth of $110 \%$ in 2002. According to the World Bank (2019), it reported that the agricultural contribution to GDP grew by $14.27 \%$ in 2018 which is higher than $11.29 \%$ recorded in 2017. The sector's output contributed $21.42 \%$ to nominal GDP in 2018. In real terms, the agricultural sector's annual growth rate for 2018 was $2.12 \%$, which was lower than the $3.45 \%$ recorded in 2017 (National Bureau of Statistics, 2018). With respect to these vicissitudes and erratic nature of the agricultural sector, several policies such as agricultural trade policy that have been formulated and deployed by the government in promoting the sector's output growth proves abortive due to the effect the Dutch disease that bedevils the country.

The excessive dependence of Nigeria on the importation and preference for foreign products including the neglect on locally produced product is alarming. The agricultural sector has experience low production output due to self-inflicted factor of massive importation of food items to feed the teeming population. The nation also lags behind in the supply of food production for her citizens (Nwanji, Lawal, Asamu and Inegbedion, 2019). It therefore results to a great deal of issues with respect to the country's agricultural advancement. The agricultural inefficiency hinders the essential opportunities for climate change mitigation and affects the sector's productivity regarding food security, unemployment, and poverty. To ensure productivity in the agricultural sector, the different trade policies ${ }^{1}$ (relating to the exchange of goods and services in the international market) adopted by the Nigerian government has not recorded much success. Meanwhile, improving the agricultural sector is a

\footnotetext{
${ }^{1}$ Trade policy defines the extent and the pattern of a country's trading with the rest of the world in order to achieve accelerated economic growth and development. The effectiveness of trade policies can be measured, among other things by the extent of growth and development which has been engendered in the economy especially in the agricultural sector.
} 
necessary condition for food security, tackling the risks associated with agrarian intensification especially for climate-smart agricultural practices.

Empirically, many studies have argued that the transformation from agriculture to industry is a movement from traditional to modern (Ikenwa et al., 2017; Sertoglu et al., 2017). Kareem (2013) affirmed that trade has an influence on agricultural performance in Nigeria. There is hardly any development plan or structural reform in Nigeria that undermines the agricultural sector. But, the problem has always been the lack of implementation of government trade policies in this direction accompanied by scanty empirical studies on this issue so far. Hence, the bone of contention still lingers as to the juxtaposition of various trade policies that will help to salvage and revamp the moribund agricultural sector and improve agricultural output forthwith. Thus, this study bridges the gap by adopting relevant variables in order to investigate the effect of trade policies on the performance of agricultural output in Nigeria from 1981-2019 with specific emphasis on trade policies after the adoption of the Structural Adjustment Programme (SAP).

Apart from this introductory part, the remaining sections of this research paper are divided into five. The major thrust of section two is the trend of Nigeria's agricultural performance in relation to Africa and the World. Section three contains the theoretical and empirical review, while the sources of data, methodology and model specification are presented in section four. Section five presents the data analysis and discussion of results, while section six is devoted to the conclusion and policy implications.

\subsection{Stylized Facts of the Nigerian Agricultural Sector}

Diversity characterizes the climatic condition in Nigeria which ranges from the tropical areas of the coast to the arid zone of the north. Thus, it makes possible to farm almost all agricultural commodities that could be cultivated in the tropical and sub-tropical regions of the world. Agricultural production all over the world has witnessed dramatic and monumental changes in terms of farming methods and output quality, but it has been the case in Nigeria (Verter, 2016). According to FAO (2016) data shows that the agricultural production in Nigeria has improved in recent decades, although at a slow rate. The share of Nigeria's agricultural production in the world and Africa slowly increased from $1.1 \%$ and $15 \%$ in 1961 to $1.6 \%$ and $17.5 \%$ in 2013 , respectively. Also, the country's share in crop production increased from 1.6\% and 19.2\% in 1961 to $2.1 \%$ and $21.5 \%$ in 2013 in the world and Africa respectively. This implies that Nigeria plays a key role in the agricultural production in Africa. In the same vein, Nigeria is ranked the tenth largest producer of agricultural products in the world with \$36billion, after China ( $\$ 538$ billion), India ( $\$ 251$ billion), the United States ( $\$ 220$ billion), Brazil ( $\$ 147$ billion), Indonesia ( $\$ 65$ billion), Russia ( $\$ 47$ billion), Argentina ( $\$ 43$ billion), Turkey ( $\$ 39$ billion) and France ( $\$ 38$ billion). Similarly, in Africa, only Nigeria was among the top twenty agricultural producers in the world in the same period. Arguably, without empirical evidence, the share of labour force in agriculture has not kept pace with its performance, but modern technologies. Given that the largest producers are also the most populous countries in the world, their working population in agriculture (that is, China, India, Indonesia, Brazil, Argentina, Turkey, Nigeria) and modern technologies (that is, USA, France, Japan) might have accounted for the variations of their production performance. From Figure 1, evidence shows that there has been upward and downward swings in the percentage contribution of agriculture to gross domestic product in Nigeria over the years of study. Importantly, the contribution of agriculture to GDP peaked in 2002 at about $36.97 \%$ and declined in the subsequent years which recently stood at $21.91 \%$ in 2019 . 
Figure 1: Trend of Agriculture, Forestry and Fishing Value added (\% of GDP)

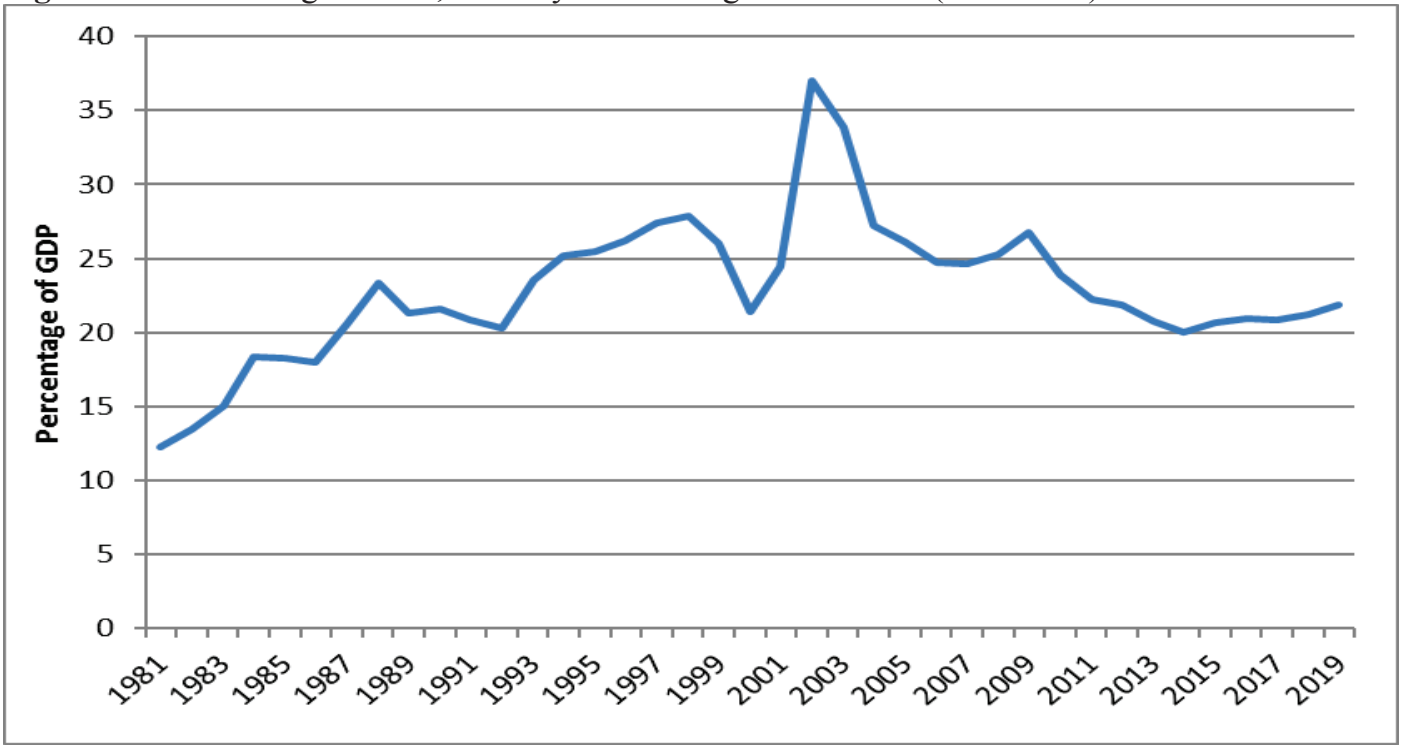

Source: World Bank Development Indicators (2020).

\subsection{Literature Review}

The section reviews import substitution strategy and export promotion strategy as it relates to the influence of trade on output growth. In addition, relevant studies relating to the study are reviewed.

\subsection{Import Substitution Strategy}

The import substitution strategy refers to set of policies implemented with the aim of improving the domestic manufacturing sector. It involves extensive use of trade policies to protect domestic industries from foreign competition. The strategyis inward-looking in that trade and industrial incentives favor production for domestic markets over the export market.

The rationale for import substitution arises from developing countries' perspective on trade. Countries in Latin America, Asia and some sub-Sahara African countries in the 1950s and 1960s have adopted the import substitution strategyin order to accelerate their development by limiting importation of manufactured goods to foster a manufacturing sector serving the domestic market. Proponents of import substitution (IS) believe that a developing economy should initially substitute domestic production of previouslyimported simple consumer goods (first-stage IS) and then substitutethrough domestic production for a wider range of more sophisticated manufactured items (second-stage IS) - all behind the protection of high tariffs andquotas on these imports. In the long run, IS advocates cite the benefits ofgreater domestic industrial diversification ("balanced growth") and the ultimateability to export some previously protected manufactured goods aseconomies of scale, low labor costs, and the positive externalities of learning bydoing cause domestic prices to become more competitive with world prices (Todaro, 2012). A principal mechanism of the import substitution strategy is the erection of protective tariffs (taxes on imports) or quotas (limits on the quantity of imports) behind which IS industries are permitted to operate. The basic economic rationale for such protection is the infant-industry argument. Tariff protection against the imported commodity is needed, so the argument goes, in order to allow the now higherpriced domestic producers enough time to learn the business and to achieve the economies of scale in production and the external economies of learning by doing that are necessary to lower unit costs and prices. Withenough time and sufficient protection, the infant will eventually grow up, bedirectly competitive with developed-country producers, and no longer need this protection.

However, against the benefits of inward-looking approach, there are some inherent disadvantages. Firstly, domestic industries can grow by being accustomed to protection from foreign competition and have no incentive to become efficient. Secondly, it can lead to inefficient industries because the narrow size of the domestic in many LDCs does not allow them to take advantage of economies of scale. Thirdly, after the simpler manufactured imports are replaced by domestic production, IS becomes more and more difficult and costly (in terms of higher protection and inefficiency) as more capital-intensive and technological advanced imports have to be replaced by domestic production. Lastly, because the whole development strategy depends on the choices made by government officials, considerable resources are devoted to rent-seeking activities. In any event, the resources used in these activities could have been devoted to productive enterprises and hence represent additional economic waste over and above deadweight loss of protection. 


\subsection{Export Promotion Strategy}

As opposed to import substitution strategy policies, some LDCs countries have adopted outward-looking strategy. These policies involve government targeting of sectors in which the country has potential comparative advantage. Thus, if a country is well endowed with low-skilled labour, the government would encourage the development of labour-intensive industries in the hope of promoting exports of these products. This type of strategy includes government policies such as keeping relatively open markets so that, internal prices reflect world prices maintaining an undervalued exchange rate so that export prices remain competitive in world markets, and imposing only minimum government interference on factor markets so that wages and rent reflect true scarcity. Under this strategy, firms get the encouragement to export in a variety of ways, such as being given increased access to credit often at subsidized rate.

The advocates of export promotion strategy believe that the competitive pressure generated by the export market is an important stimulus to efficiency and modernization. The only way a firm can succeed in the face of intense international competition is to produce what consumers want, at the quality they want, and at the lowest possible costs.However, the export promotion strategy is deficient in some ways. Firstly, it may be very difficult for LDCs to set up export industries because of the competition from the more established and efficient industries in developed nations. Secondly, developed nations often provide a high level of effective protection for their industries producing simple labour-intensive commodities in which LDCs already have or can soon acquire a comparative advantage (Todaro, 2012).

\subsection{Empirical Review}

On the empirical fronts, relatively few studies have been conducted on the effect of trade policies on agricultural output in Nigeria. The searchlight on the trade policies effect on agricultural output is beamed on Manniand Afzal (2012) study the effect of trade liberalization on economic growth of developing countries: A case of Bangladesh economy. Using Ordinary Least Square estimation (OLS) technique and employing variables like trade liberalization measured by export plus import divided by GDP, import, export and inflation. The result confirmed a positive andsignificant relationship between openness and growth but the effect of growth in capital on GDP turned out to be negative and statistically insignificant, it also showed that both real exports and imports have increased with greater openness. Seetanah, Matadeen and Matadeen (2012) researched trade openness and economic performance: An African perspective. Their variables included investment ratio proxied by country's investment divided by its GDP, openness measured by total export plus import divided by GDP, secondary enrolment ratio, financial development and FD1 they used panel vector auto regression (VAR) model estimates. Then study shows a bi-causal relationship between openness and economic growth. Openness induced growth and an increase in GDP leads to a rise in the openness of the country. They found out that openness indirectly promotes growth through financial development and foreign direct investment.

Djokoto (2013) conducted a research on openness and agricultural performance in Ghana. His main focus was openness and foreign direct investment (FDI). The variables he employed were agricultural performance which used agricultural GDP as a ratio of GDP as a proxy, bank credit to agriculture form deposit money banks as a ratio of total GDP, real effective exchange rate, inflation, FDI and agricultural openness. He found out that, an increase in foreign direct investment brought about a decline in the performance of the agricultural sector and a decrease in openness of the economy brought about an increase in the performance of the sector.

Evidences from Nigeria are instrumental in this review. The investigation by Adekunle and Ndukwe (2018) examined the possible impact of dynamic asymmetric variations in the real exchange rate on the output of Nigerian agricultural sector from 1981 to 2016. It utilizes the Bounds cointegration test and reports no impact ofasymmetric changes of real exchange rate on the output of agriculture. This study specifically, seeks to establish the individual and joint impact of the macroeconomic variables (inflation rate, real external reserves, nominal exchange rate, real per capita GDP as a proxy of aggregate demand shock, commercial interest rate (proxy for lending rate to agricultural sector), employment in agriculture (\% of total employment) and oil revenue as a ratio of GDP) on the agricultural output both in the short and the long run links between agricultural productivity and some key macroeconomic fundamentals. Enilolobo, Mustapha and Supo-Orija (2019) investigated the effect of macroeconomics indicators dynamics on agricultural output in Nigeria using Fully Modified Ordinary Least Squares (FMOLS). The results show thatinflation rate in Nigeria is volatile over the period of study and inflation volatility has a negative but significant impact on agricultural growth. Exchange rate and cost of fund also possess varying positive impacts on agricultural output. Also, Onakoya, Bola and Babatunde (2018) examined the impact of macroeconomic variables on the Nigerian value- added agricultural output from 1971-2016 using Vector Error Correction Model (VECM). The results show that in the long run inflation rate, exchange rate and agricultural employment rates were positively related and significant with value-added agricultural output. However, interest rate, external reserves, aggregate demand shock and oil revenue are significant but negatively related to value-added agricultural output. Samuel et al. (2019) examined the empirical analysis of Agricultural production: The sway of Economic Growth in Nigeria between 1985-2015 
using Ordinary Least Square (OLS). The study found a significant relationship between interest rate and economic growth in Nigeria. In the same vein, Ojeka (2016) studied the constraints to agricultural development in Nigeria between 1970-2010 using Error Correction Mechanism. Findings show that exchange rate, food export has most significant impact on agricultural output in Nigeria.

\subsection{Methodology}

\subsection{Model Specification}

This study adapts and modifies the work of Nwaji et al. (2019) to investigate the role of trade policy on agricultural performance in Nigeria. The research paper regresses agricultural performance measured as the ratio of agricultural output to gross domestic product (GDP) on trade policies proxy by trade openness (the division of the addition of export and import to GDP) and exchange rate, including real interest rate proxy for monetary policy. Based on existing literature, interest rate was added as control variables to better strengthen the assessment of the model. It is believed that low interest rate will boost investment which will result to high performance in the agricultural sector. The function form of the empirical model is specified as:

$A G O_{t}=f\left(T O P_{t}, E_{X C H R_{t}}\right.$ INTR $\left._{t}\right)$

Thus, the stochastic form of the model is specified as:

$$
A G O_{t}=\beta_{0}+\beta_{1} T O P_{t}+\beta_{2} E_{X C H R_{t}}+\beta_{3} I N T R_{t}+\mu_{t}
$$

Where $A G O$ denotes agricultural output; TOP represents trade openness; INTR is interest rate; EXCHR indicates exchange rate; $\beta_{0}, \beta_{1-3}$ are parameters; $\mu$ denotes stochastic term; and $t$ is time. With respect to the theoretical a priori expectation, it is expected that $\beta_{1}$ to have a positive relationship with agricultural output that is an increase in trade openness led to an increase in the performance of agricultural sector. Meanwhile, $\beta_{2}$ can either be positive or negative depending on the exchange rate situation of a country i.e. appreciation or depreciation of the local currency. As for interest rate, $\beta_{3}$ is expected to have a negative value, indicating an indirect relationship with agricultural performance.

\subsection{Data and Estimation Technique}

The data series covered the periods of 1981-2019. The secondary data were obtained from the database of World Bank - World Development Indicators and the Central Bank of Nigeria Annual Statistical Bulletin. The study utilized the autoregressive distributed lag model (ARDL) proposed by Pesaran and Shin (1997). The use of ARDL cointegration approach, rather than the conventional Johansen cointegration testing, was hinged on some features of the former that include: a mixture of $\mathrm{I}(0)$ and $\mathrm{I}(1)$ data, assigning different lag-lengths for different variables as they enter the model; it did not require unit root testing, which is a prerequisite in the conventional approach; it could be used regardless of whether the underlying variables are I(0), I(1) of fractionally integrated; and this is coupled with the fact that it involves just a single-equation set-up, making it simple to implement and interpret. The ARDL-bound test regression is theoretically specified as thus:

$$
\begin{aligned}
& \triangle A G O_{t}=\phi_{0}+\phi_{1} A G O_{t-1}+\phi_{2} T O P_{t-1}+\phi_{3} E_{X C H R_{t-1}}+\phi_{4} I N T R_{t-1}+\sum_{i=1}^{p} \varphi_{1} \Delta A G O_{t-1}+ \\
& \sum_{i=1}^{p} \varphi_{2} \Delta T O P_{t-1}+\sum_{i=1}^{p} \varphi_{3} \Delta E X C H R_{t-1}+\sum_{i=1}^{p} \varphi_{4} \Delta I N T R_{t-1}+\varepsilon_{t}
\end{aligned}
$$

Following from establishment of ARDL framework, as demonstrated in equation (3), the next step was to estimate the ARDL form of the equation, where the optimal lag length was chosen according to one of the standard criteria, such as the Akaike Information Criterion (AIC) or Schwartz Bayesian Criterion (SBC). The restricted version of the equation was then solved for the long-run solution. F-test statistic was used for testing the existence of long-run relationship in equation (1), where the null hypothesis of no long-run relationship was defined by: $H_{0}: \varphi_{1}=\varphi_{2}=\varphi_{3}=\varphi_{4}=0$ against the alternative hypothesis that is, $H_{1}: \varphi_{1} \neq \varphi_{2} \neq \varphi_{3} \neq \varphi_{4} \neq 0$ was not true. The F-test had a non-standard distribution which depended on: (i) whether the variables included in the ARDL model were to be I(0) or I(1), (ii) whether the ARDL model contained an intercept and/or trend. Pesaran and Pesaran (1997) reported two sets of critical values (CVs): one set was calculated assuming that all variables included in the ARDL model were I(1), while the other was estimated considering the variables as $\mathrm{I}(0)$. Where the calculated F-statistic was higher that the upper bound critical value, it suggested rejection of the null hypothesis of no long-run relationship. Where the calculated Fstatistic was lower than the lower bound of the critical value, then the null hypothesis was not rejected. But if it fell in between the lower and upper bound, then the result is inconclusive. To confirm the short-run dynamics of 
the model, the first lag of the levels of each variable was added to the equation to create the error correction mechanism $(\mathrm{ECM})$ equation. The ECM equation is specified as:

$$
\begin{aligned}
& \triangle A G O_{t}=\gamma_{0}+\sum_{i=1}^{a} \gamma_{1} \Delta A G O_{t-1}+\sum_{i=1}^{b} \gamma_{2} \Delta T O P_{t-1}+\sum_{i=1}^{c} \gamma_{3} \Delta E X C H R_{t-1}+\sum_{i=1}^{d} \gamma_{4} \Delta I N T R_{t-1}+ \\
& \lambda_{1} E C T_{t-1}+e_{t}
\end{aligned}
$$

The error correction term (ECT) is the OLS residuals series from the long-run cointegrating regression. The ECM has high potency in estimating both long-run and short-run effects (parsimonious). However, it must be noted that the a-priori expectation of this study was that the coefficient of ECT (-1) will be significant for longrun equilibrium to exist. The coefficient had a negative sign (this was necessary for it to perform the role of error correction); and should be less than one (that is, its value tells the percentage corrected for each period and this is not expected to be $100 \%$ ).

\subsection{Results and Discussion}

This study presents the descriptive statistics and correlation analysis of the variables in Table 1 . The average values of agricultural performance, trade openness, exchange rate and interest rate were $22.84 \%, 32.3 \%$, 94.14 per US Dollar and 13.08\% respectively. Their standard deviation values stood at 4.7\%, 12.4\%, $\$ 92.82$ per US Dollar and $4.05 \%$ correspondingly. The results indicate that exchange rate is more volatile among the variables under studied. Also, the output of the summary statistics shows that only trade openness is negatively skewed while others skewed rightward. The Kurtosis test confirmed that the variables are not normally distributed because they are platykurtic. The correlation analysis shows that trade openness, exchange rate and interest rate have positive correlation with agricultural performance. Likewise, exchange rate and interest rate have positive level of association with trade openness. Meanwhile interest rate and exchange rate have negative correlation.

Table 1: Summary statistics and correlation analysis

\begin{tabular}{lllll}
\hline Summary statistics & AGO & TOP & EXCHR & $I N T R$ \\
\hline Mean & 22.837 & 32.301 & 94.143 & 13.077 \\
Standard Deviation & 4.704 & 12.404 & 92.822 & 4.047 \\
Kurtosis & 1.928 & -0.684 & 0.005 & 1.692 \\
Skewness & 0.478 & -0.384 & 0.843 & 0.696 \\
Minimum & 12.240 & 9.136 & 0.618 & 6 \\
Maximum & 36.965 & 53.278 & 306.921 & 26 \\
Count & 39 & 39 & 39 & 39 \\
\hline Correlation analysis & & & & EXCHR \\
\hline & $A G O$ & $T O P$ & & \\
\hline AGO & 1 & & & \\
TOP & 0.6232 & 1 & 1 & \\
EXCHR & 0.1769 & 0.2674 & & \\
INTR & 0.3354 & 0.3135 & -0.0376 & 1 \\
\hline
\end{tabular}

Source: Author's computation (2021).

The unit root test using the Augmented Dickey and Fuller (ADF), Phillips-Perron (PP) and KwiatkowskiPhillips-Schmidt-Shin (KPSS) tests are reported in Table 2.

\begin{tabular}{|c|c|c|c|c|c|c|c|}
\hline \multirow[b]{2}{*}{ Variables } & \multicolumn{2}{|c|}{ ADF } & \multicolumn{2}{|c|}{$\mathbf{P P}$} & \multicolumn{2}{|c|}{ KPSS } & \multirow{2}{*}{$\begin{array}{c}\text { Order of } \\
\text { integration }\end{array}$} \\
\hline & At level & $\begin{array}{c}\text { At 1st } \\
\text { Difference }\end{array}$ & At level & $\begin{array}{c}\text { At 1st } \\
\text { Difference }\end{array}$ & At level & $\begin{array}{c}\text { At 1st } \\
\text { Difference }\end{array}$ & \\
\hline $\mathrm{AGO}$ & -1.944 & $-7.216^{* * *}$ & -2.182 & $-8.071 * * *$ & 0.216 & $0.061 * * *$ & $\mathrm{I}(1)$ \\
\hline TOP & -2.367 & $-4.656 * * *$ & -2.288 & $-9.913 * * *$ & 0.193 & $0.111 * * *$ & $\mathrm{I}(1)$ \\
\hline EXCHR & -2.079 & $-4.505^{* * *}$ & -1.511 & $-4.248 * * *$ & $0.143 * *$ & $0.062 * * *$ & $\mathrm{I}(1)$ \\
\hline INTR & $-3.908 * * *$ & - & $-4.091 * * *$ & - & $0.130 * *$ & - & $\mathrm{I}(0)$ \\
\hline
\end{tabular}

Table 2: Unit root Test

Note: $* * * *$ and $*$ denote significance at $1 \%, 5 \%$ and $1 \%$ respectively. The null hypothesis $\left(\mathrm{H}_{0}\right)$ for $\mathrm{ADF}$ and PP: Unit root while the null hypothesis $\left(\mathrm{H}_{0}\right)$ for KPSS: Stationary. The optimal lag order for ADF test is determined by AIC, while the bandwidths for PP and KPSS are determined by using the Newey-West Bartlett kernel.

Source: Author's computation (2021).

Furthermore, it is important to note that both the Augmented Dicky Fuller (ADF) unit root test proposed by Dickey and Fuller (1979) and Phillips-Perron (PP) unit root test proposed by Phillips and Perron (1988) determine if the series exhibit an evidence of unit root (nonstationary series) while the Kwiatkowski-PhillipsSchmidt-Shin (KPSS) stationary test proposed by Kwiatkowski et al. (1992) determine the evidence of 
stationarity in the series. The results show that at the conventional level, agricultural performance, trade policy and exchange rate are integrated of order one while interest rate is integrated of order zero. It implies that agricultural performance, trade policy and exchange rate are stationary at first difference, whereas, interest rate is stationary at levels. Thus, the ARDL bound test analysis is most appropriate for ascertaining if the series exhibit a long run relationship.

Table 3: Bound Test of Cointegration using ARDL $(2,2,4,4)$

\begin{tabular}{llll}
\hline \multirow{2}{*}{ F-statistics } & \multicolumn{2}{l}{ Critical value @ 5\% } & \multirow{2}{*}{ Decision } \\
\cline { 2 - 3 } & $\mathbf{I}(\mathbf{0})$ & $\mathbf{I}(\mathbf{1})$ & Cointegration exists \\
\hline 5.757 & 2.79 & 3.67 & \\
\hline
\end{tabular}

Null Hypothesis: No long run relationship exist

Source: Author's computation (2021).

After confirming that the empirical model has variables with order of integration zero and one, the ARDL bound test for cointegration proposed by Pesaran et al. (2001) was employed to carry out the long-run relationship between the variables with the null hypothesis of no long-run relationship. The result presented in Table 3 indicates that we do not accept the null hypothesis of no long-run relationship among the variables. The F-statistics value of 5.757 is greater than the upper bound (I(1)) value of 3.67. Hence, there exists a cointegrating relationship between trade policy and agricultural output in Nigeria.

Table 4: ARDL Short-run and Long-run Results of Agricultural Performance

Dependent Variable: D(AGO)

Selected Model: ARDL(2, 2, 4, 4)

Sample: 19812019

Included observations: 35

\begin{tabular}{|c|c|c|c|c|}
\hline \multicolumn{5}{|c|}{ Short-Run Estimates } \\
\hline Variable & Coefficient & Std. Error & t-Statistic & Prob. \\
\hline$\overline{\Delta(\mathrm{AGO}(-1))}$ & 0.367633 & 0.130967 & 2.807060 & 0.0112 \\
\hline$\Delta(\mathrm{TOP})$ & -0.048594 & 0.050002 & -0.971840 & 0.3433 \\
\hline$\Delta(\mathrm{TOP}(-1))$ & -0.087996 & 0.051137 & -1.720787 & 0.1015 \\
\hline$\Delta(\mathrm{EXCHR})$ & 0.016880 & 0.020040 & 0.842344 & 0.4101 \\
\hline$\Delta(\operatorname{EXCHR}(-1))$ & 0.009961 & 0.024346 & 0.409132 & 0.6870 \\
\hline$\Delta(\operatorname{EXCHR}(-2))$ & 0.055626 & 0.026006 & 2.138953 & 0.0456 \\
\hline$\Delta(\operatorname{EXCHR}(-3))$ & 0.102284 & 0.023586 & 4.336645 & 0.0004 \\
\hline$\Delta(\mathrm{INTR})$ & -0.136874 & 0.113537 & -1.205547 & 0.2428 \\
\hline$\Delta(\operatorname{INTR}(-1))$ & -0.290057 & 0.143136 & -2.026445 & 0.0570 \\
\hline$\Delta(\operatorname{INTR}(-2))$ & -0.423262 & 0.133561 & -3.169043 & 0.0051 \\
\hline$\Delta(\operatorname{INTR}(-3))$ & -0.248380 & 0.105934 & -2.344672 & 0.0301 \\
\hline $\operatorname{ECT}(-1)$ & -0.660628 & 0.111918 & -5.902785 & 0.0000 \\
\hline
\end{tabular}

\begin{tabular}{|c|c|c|c|c|}
\hline \multicolumn{5}{|l|}{ Long-Run Estimates } \\
\hline Variable & Coefficient & Std. Error & t-Statistic & Prob. \\
\hline TOP & 0.170813 & 0.063806 & 2.677074 & 0.0149 \\
\hline EXCHR & -0.033909 & 0.015348 & -2.209354 & 0.0396 \\
\hline INTR & 0.013846 & 0.252371 & 0.054865 & 0.9568 \\
\hline $\mathrm{C}$ & 19.23026 & 3.751503 & 5.126015 & 0.0001 \\
\hline R-squared & 0.741745 & \multicolumn{2}{|c|}{ Durbin-Watson stat } & 1.843546 \\
\hline Adjusted R-squared & 0.618232 & \multicolumn{2}{|c|}{ F-Statistics(Prob.) } & $7.429(0.000)$ \\
\hline \multicolumn{5}{|l|}{ Diagnostic Tests } \\
\hline Normality test & $0.063(0.9689)$ & \multirow{2}{*}{\multicolumn{2}{|c|}{ Heteroskedasticity test }} & $1.526(0.2311)$ \\
\hline Serial Correlation & $1.900(0.1800)$ & & & $1.574(0.2191)$ \\
\hline
\end{tabular}

Source: Author's computation (2021).

Furthermore, the ARDL approach is utilized to estimate both the short-run and long-run impact of trade policy on agricultural performance, which is presented in Table 4 . The findings show that trade openness contributes positively and significantly to agricultural output in Nigeria both in the short-run and in the long-run which is consistent with the theoretical a-priori expectation. The coefficients of trade openness in the short-run and the long-run are 0.088 and 0.1708 . This implies that if trade openness goes up by $10 \%$, an average value of agricultural performance will rise by $0.88 \%$ and $1.71 \%$ in the short-run and long-run respectively. The results showed that trade openness contribute more to agricultural performance in the long-run than in the short-run. Likewise, there exists a significant relationship between exchange rate and agricultural performance in Nigeria. Meanwhile, the relationship between exchange rate and agricultural performance in short-run is positive but 
negative in the long-run. The negative relationship between exchange rate and agricultural performance in the long-run follows the theoretical expectation. The result in the long-run negates the findings of Onakoya et al. (2018) and Enilolobo et al. (2019). In magnitude terms, a decrease in exchange rate (currency appreciation) by one standard deviation will lead to an increase in agricultural performance by $0.34 \%$ in the long-run. This is so because of the deliberate attempt by the monetary authority to devalue the currency and permit a flexible exchange rate as opposed to a fixed exchange rate so as to make importation dearer and exportation relatively cheaper.

As for interest rate, the short-run coefficients are negative and significant at 5\% level while the long-run estimate is positive and insignificant at the conventional level. This indicates that low interest rate only contributed to agricultural performance in the short-run. Meanwhile, the impact of interest rate on long-run agricultural performance is not established which corroborate with the findings of Onakoya et al. (2018). Thus, a $10 \%$ changes in the first, second and third lags of interest rate improve agricultural performance by $2.90 \%$, $4.23 \%$ and $2.48 \%$ respectively. The result can be attributed to central bank monetary regulations and directives on interest rate charged on loans of other sectors at a higher rate, this will invariably make credit available for the agricultural sector thereby improving agricultural performance only in the short-run. The coefficient of error correction term (ECT) is negative and significant thereby suggesting a long-run equilibrium reversion from the short run economic shocks in Nigeria by $66.06 \%$ per annum. The implication is that it will take agricultural sector about a year to adjust fully to transitory shock and be steady-state. The diagnostic tests showed that the error terms are normally distributed, uncorrelated, and constant variance. The model is well-specified as indicated by the Ramsey RESET test.

\subsection{Conclusion and Policy Implications}

This research paper investigates the role of trade policy in the performance of agricultural sector in Nigeria. The study adopted a secondary data by regressing agricultural performance (proxy by the ratio of agricultural output to GDP) on trade policy (measured by trade openness and exchange rate) and real interest rate. The time period spans within 1981 and 2019. The ARDL co-integration approach to bond test confirmed that there exist a longrun relationship between trade policy and agricultural performance in Nigeria. The result showed that trade openness has a significant and positive effect on agricultural performance in Nigeria. Further, the study confirmed that trade openness contributes more to agricultural performance in the long-run than in the short-run. However, exchange rate impacted negatively and significantly on agricultural performance in the long-run. Meanwhile, the short-run estimates showed that exchange rate has a significant and positive effect on agricultural performance. More so, it was gathered that interest rate affects agricultural performance negatively in Nigeria. In terms of policy relevance, the outcome of this enquiry provides some interesting insights. Hence, the study therefore recommends that:

1) The government should embark on outward looking trade policy that encourages the export of indigenous produced agricultural products and thereby stimulating agricultural output.

2) The monetary authority that is, central bank should assist in stabilizing the country's currency against foreign currency and should discourage unnecessary importation of food products by imposing stringent monetary policies.

3) The central bank should give special directives to commercial banks in order to make credit facilities available to the agricultural sector at a reduced cost of capital.

\section{References}

Adekunle, W. and Ndukwe, C. I. (2018). "The Impact of Exchange Rate Dynamics on Agricultural Output Performance in Nigeria". International Economics eJournal.

Anyanwu, J.C. (1997). "The Structure of the Nigerian Economy". Onitsha: Joanee Educational Publishers.

Auty, R. M. (1993). "Sustaining Development in Mineral Economies: The Resource Curse Thesis". London: Routledge.

Dickey, D and Fuller, W. (1979). Discussion of the Estimators for an Autoregressive Time Series with a Unit Root. Journal of American Statistical Association, 74, 427-431.

Djokoto,J.G.(2013).“Openness and Agricultural Performance in Ghana”.Journal of Science and Technology, 33(2), pp. 24-36.

Enilolobo, O.S., Mustapha, S. A. and Supo-Orija, F. O. (2019). "Effect of Macroeconomic Indicators on Agricultural Output in Nigeria". Global Journal of Management and Research: Economics and Commerce, 19(4).

F.A.O. (2016). FOSTAT database. Available at http://bit.ly/NmQzZf. (Accessed $10^{\text {th }}$ February, 2016.

Ikenwa, K. O., Sulaimon, A. A., \&Kuye, O. L. (2017). Transforming the Nigerian Agricultural Sector into an Agribusiness Model- The Role of Government, Business and Society. ActaUniversitatisSapientiae, Economics and Business, 5(1), 71-115Nigerian National Bureau of Statistics. (2018). E-library. 
Kareem, N. O. (2013). “Analysis of Factors Influencing Agricultural Output in Nigeria: Macroeconomic Perspectives”. American Journal of Business, Economics and Management, 1(1), 9-15.

Kwiatkowski, D., Phillips, P. C., Schmidt, P., \& Shin, Y. (1992). Testing the Null Hypothesis of Stationarity against the Alternative of Unit Root. Journal of Econometrics, 54(1-3), 159-178.

Manni, U. H. and Afzal, M. N. (2012). "Effect of Trade Liberalization on the Economic Growth of Developing Countries: A case of Bangladesh Economy". Journal of Business, Economics and Finance, (1)2.

Nwanji, T. I., Lawal, A. I., Asamu, F. and Inegbedion, H. (2019). "Effects of Foreign Trade on Agricultural Output in Nigeria”. International Journal of Mechanical Engineering and Technology, 10(3), 295-304.

Ojeka, G. O. (2016). "Constraints to Agricultural Development in Nigeria". International Journal of Development and Economic Sustainability, 4(2), 1-15

Onakoya, A. B., Bola, A. and Babatunde, S. J. (2018). "Value Added Agricultural Output and Macroeconomic Dynamics in the Nigerian Economy". Kampala International University Journal of Humanities, 3(4),79-91.

Pesaran, M. H., and Pesaran, B. (1997). Microfit 4.0: Interactive Econometric Analysis, Oxford University Press.

Pesaran, M. H., and Shin, Y. (1997). “An Autoregressive Distributed Lag Modelling Approach to Co-integration analysis". A revised version of a paper presented at the symposium at the Centennial of Ragnar Frisch, the Norwegian Academy of Science and Letters, Oslo, March3-5, 1995.

Phillip, P. C. and Perron, P. (1988). "Testing for Unit Roots in Time Series Regression”. Biometrica, 75, $335-$ 346.

Samuel, W. A., Usanga, S. U. and David, M. (2019). "An Empirical Analysis of Agricultural Production: The Sway of Economic Growth in Nigeria". Journal of Applied Research, 5(1), 2170-2199.

Seetanah, Matadeen and Matadeen, (2012)."Trade Openness and Economic Performance: An African Perspective".

Sertoglu, K., Ugural, S., \&Bekun, F. V. (2017). The Contribution of Agricultural Sector on Economic Growth in Nigeria. International Journal of Economics and Financial Issues, 7(1), pp. 547-552.

The World Bank Group. (2019). World development indicators. https://data.worldbank.org.

Todaro, M.P. and Smith, S. C. (2012). "Economic development". $11^{\text {th }}$ edition.

United Nations Department of Economic and Social Affairs: Population Division. (2019). Online resources.

Verter, N. (2016). "Analysis of External Influences on Agricultural Performance in Nigeria". ACTA UniversitatisAgriculturaeet SilviculturaeMendelianaeBrunensis, 64(5), pp. 1805-1821. 